Check for updates

BMJ, London, UK

kabbasi@bmi.com

Cite this as: BMJ 2021;372:n314 http://dx.doi.org/10.1136/bmj.n314 Published: 04 February 2021

\section{Covid-19: Social murder, they wrote-elected, unaccountable, and unrepentant}

\author{
After two million deaths, we must have redress for mishandling the pandemic
}

\section{Kamran Abbasi executive editor}

Murder is an emotive word. In law, it requires premeditation. Death must be deemed to be unlawful. How could "murder" apply to failures of a pandemic response? Perhaps it can't, and never will, but it is worth considering. When politicians and experts say that they are willing to allow tens of thousands of premature deaths for the sake of population immunity or in the hope of propping up the economy, is that not premeditated and reckless indifference to human life? If policy failures lead to recurrent and mistimed lockdowns, who is responsible for the resulting non-covid excess deaths? When politicians wilfully neglect scientific advice, international and historical experience, and their own alarming statistics and modelling because to act goes against their political strategy or ideology, is that lawful? Is inaction, action? ${ }^{1}$ How big an omission is not acting immediately after the World Health Organization declared a public health emergency of international concern on 30 January 2020 ?

At the very least, covid-19 might be classified as "social murder," as recently explained by two professors of criminology. ${ }^{2}$ The philosopher Friedrich Engels coined the phrase when describing the political and social power held by the ruling elite over the working classes in 19th century England. His argument was that the conditions created by privileged classes inevitably led to premature and "unnatural" death among the poorest classes. ${ }^{3}$ In The Road to Wigan Pier, George Orwell echoed these themes in describing the life and living conditions of working class people in England's industrial north. ${ }^{4}$ Today, "social murder" may describe the lack of political attention to social determinants and inequities that exacerbate the pandemic. Michael Marmot argues that as we emerge from covid-19 we must build back fairer.

\section{International accountability}

A pandemic has implications both for the residents of a country and for the international community, so sovereign governments should arguably be held accountable to the international community for their actions and omissions on covid-19. Crimes against humanity, as adjudicated by the International Criminal Court, do not include public health. ${ }^{6}$ But David Scheffer, a former US ambassador for war crimes, suggests that we could broaden the application of public health malpractice "to account for the administration of public health during pandemics." In that case, public health malpractice might become a crime against humanity, for leaders who intentionally unleash an infectious disease on their citizens or foreigners. Others have argued similarly for environmental crimes. ${ }^{8}$

If not murder or a crime against humanity, are we seeing involuntary manslaughter, misconduct in public office, or criminal negligence? Laws on political misconduct or negligence are complex and not designed to react to unprecedented events, but as more than two million people have died, we must not look on impotently as elected representatives around the world remain unaccountable and unrepentant. What standard should leaders be judged by? Is it the small number of deaths in countries such as New Zealand and Taiwan, or the harsher standard of zero excess deaths? Deaths do not come as single spies but as a battalion of bereaved families, shattered lives, long term illness, and economic ruin.

From the United States to India, from the United Kingdom to Brazil, people feel vulnerable and betrayed by the failure of their leaders. The over 400 ooo deaths from covid-19 in the US, 250 ooo in Brazil, 150000 each in India and Mexico, and 100000 in the UK comprise half of the world's covid death toll-on the hands of only five nations. ${ }^{9}$ Donald Trump was a political determinant of health who damaged scientific institutions. ${ }^{10}$ He suffered electoral defeat, but does Trump remain accountable now that he is out of office? Bolsonaro, Modi, and Johnson have had their competence questioned in differing ways, and McKee and colleagues argue that populist leaders have undermined pandemic responses. ${ }^{11}$ The prospect of accountability in autocracies such as China and Russia is more distant still and relies on strong international institutions and the bravery of citizens.

More than a few countries have failed in their response to the virus; the global missteps are many and well documented by the Independent Panel for Pandemic Preparedness and Response. ${ }^{12} 13$ Its report calls for comprehensive use of non-pharmaceutical interventions-the means, they say, by which these interventions curb a pandemic are "well known"-and for governments to support equity, reinvent and modernise the global pandemic alert system, take pandemic threats seriously, and cooperate better with other nations and WHO. Acting urgently and collaboratively in these areas will allow the world to be best prepared for any future pandemic.

\section{Hollow excuses}

But the global picture does not absolve individual leaders and governments from responsibility. ${ }^{14}$ Many of the independent panel's conclusions place the blame squarely at the doorsteps of rulers, although you will be hard pressed to find a single politician 
who has admitted responsibility for the extent of premature death, let alone resigned. Several have expressed contrition, but "sorry" rings hollow as deaths rise and policies that will save lives are deliberately avoided, delayed, or mishandled.

Others say they have done all they can or that the pandemic was uncharted territory; there was no playbook. None of these are true. They are self-serving political lies from the "gaslighters in chief" around the globe. ${ }^{15}$ Some attempt to defend their record by claiming that their country has done more testing, counts deaths better, or has more obesity and population density. All of these may contribute, but counting methods or population factors do not explain the sheer scale of the variation in performance.

If citizens feel disempowered, who might hold negligent politicians to account? Experts in science might do so, but official scientific advisers have often struggled to convince politicians to act until it is too late or kept silent to avoid public criticism. So might doctors, with their responsibilities to public health. ${ }^{16}$

The media might help here, remembering their duty to speak truth to power, to hold elected officials accountable. And yet much of the media is complicit too, trapped in ideological silos that see the pandemic through a lens of political tribalism, worried about telling pandemic truths to their readers and viewers, owners, and political friends. In fact, truth has become dispensable as politicians and their allies are allowed to lie, mislead, and repaint history, with barely a hint of a challenge from journalists and broadcasters. Anybody who dares to speak truth to power is unpatriotic, disloyal, or a "hardliner."

Ministers in the UK, for example, interact with the media through sanitised interviews, stage managed press conferences,

off-the-record briefings to favoured correspondents, and, when the going gets tough, by simply refusing to appear. It is this environment that has allowed covid denial to flourish, for unaccountability to prevail, and for the great lies of "world beating" pandemic responses to be spun. "The most important lessons from this pandemic," argue Bollycky and Kickbusch, "are less about the coronavirus itself but what it has revealed about the political systems that have responded to it." 17

How many excess deaths does it take for a chief scientific or medical adviser to resign? How long should test and trace fail the public before a minister of health or chief adviser steps down? How many lucrative contracts for unscientific diagnostic tests that are awarded to cronies or errors in education policy will lead to a ministerial sacking?

\section{Getting redress}

Where then should citizens turn for accountability, if they don't find it in their leaders and feel unsupported by experts and the media? The law remains one form of redress, and indeed some legal avenues, including criminal negligence and misconduct in public office, are being explored, ${ }^{18} 19$ although proving any such claims will be difficult and drawn out. But the notion of murder, at least "social murder," is hard to shake emotionally, and strengthens with every denial of responsibility and every refusal to be held accountable or to change course.

That leaves three options. The first is to push for a public inquiry, as The $B M J$ and others argued for in the summer of $2020^{20}-$ a rapid, forward looking review rather than an exercise in apportioning blame that will identify lessons and save lives. The second is to vote out elected leaders and governments that avoid accountability and remain unrepentant. The US showed that a political reckoning is possible, and perhaps a legal one can follow, although research suggests that mishandling a pandemic may not lose votes. ${ }^{21}$ The third is for mechanisms of global governance, such as the International Criminal Court, to be broadened to cover state failings in pandemics.

In the UK, which was responsible for about $1 \%$ of global deaths in the 1918-19 flu pandemic and now accounts for $5 \%$ with a smaller proportion of the world's population, ${ }^{922}$ elections are a few years off. As the current government holds a parliamentary majority, avenues for redress seem blocked. What's left in these circumstances is for citizens to lobby their political representatives for a rapid public inquiry; for professionals in law, science, medicine, and the media, as well as holders of public office, to put their duty to the public above their loyalty to politicians and to speak out, to dissent lawfully, to be active in their calls for justice, especially for disadvantaged groups.

The "social murder" of populations is more than a relic of a bygone age. It is very real today, exposed and magnified by covid-19. It cannot be ignored or spun away. Politicians must be held to account by legal and electoral means, indeed by any national and international constitutional means necessary. State failures that led us to two million deaths are "actions" and "inactions" that should shame us all.

Competing interests: I have read and understood BMJ policy on declaration of interests and have no relevant interests to declare.

Provenance and peer review: Commissioned; externally peer reviewed.

Farrar JJ. Stopping the gaps in epidemic preparedness. N Engl J Med 2019;380:1788-9. doi: 10.1056/NEJMp1902683 pmid: 31067366

2 The failings behind the UK's abysmal death toll. Guardian 2021 Jan 27. https://www.theguardian.com/world/2021/jan/27/the-failings-behind-the-uks-abysmal-death-toll

Engels F. [1845]. The condition of the working-class in England. Cosimo, 2009:95. Orwell G. The road to Wigan pier. Harvill Secker, 1937.

Marmot M, Allen J, Goldblatt P, Herd E, Morrison J. Build back fairer: the covid-19 Marmot review. 2020 http://www.instituteofhealthequity.org/resources-reports/build-back-fairer-the-covid-19marmot-review

6 International Criminal Court. Rome statute. 1988. https://www.icc-cpi.int/resource-library/documents/rs-eng.pdf

7 Scheffer D. Is it a crime to mishandle a public health response? Foreign Affairs 2020 Apr 22. https://www.cfr.org/article/it-crime-mishandle-public-health-response

$8 \quad$ Ngira D, Okoth M. Conceptualizing environmental crimes as crimes against humanity: a philosophical justification. SSRN 2015. [Preprint.] https://ssrn.com/abstract=2674065doi: $10.2139 /$ ssrn 2674065

9 Worldometer. Reported cases and deaths by country or territory, 3 Feb 2021. https://www.worldometers.info/coronavirus/

10 Yamey G, Gonsalves G. Donald Trump: a political determinant of covid-19. BM/2020;369:m1643. doi: 10.1136/bmj.m1643 pmid: 32332028

11 McKee M, Gugushvili A, Koltai J, Stuckler D. Are populist leaders creating the conditions for the spread of covid-19? Int J Health Policy Manag 2020; [Epub ahead of print.]. doi: 10.34172/ijhpm.2020.124. pmid: 32668893

12 Independent Panel for Pandemic Preparedness and Response. Second report on progress. 2021 https://theindependentpanel.org/wp-content/uploads/2021/01/Independent-PaneL_Second-Reporton-Progress_Final-15-Jan-2021.pdf

13 Wenham C. What went wrong in the global governance of covid-19. BMJ2021;372.n303. doi: 10.1136/bmj.n303.

14 Institute for Government. Government's covid-19 decision making hindered by lack of strategy and planning. 2020. https://www.instituteforgovernment.org.uk/news/latest/government-covid19-decision-making

15 Abbasi K. Covid-19: politicisation, "corruption,” and suppression of science. BM/2020;371:m4425. doi: 10.1136/bmj.m4425 pmid: 33187972

16 Ashton J. Blinded by corona. Gibson Square, 2020

17 Bollyky TJ, Kickbusch I. Preparing democracies for pandemics. BMJ 2020;371:m4088. doi: 10.1136/bmj.m4088 pmid: 33097482

18 lacobucci G. Covid-19: UK prime minister says he will only meet bereaved families when they drop threat of legal action. BMJ 2020;370:m3424. doi: 10.1136/bmj.m3424 pmid: 32878884 
19 Boyle D. Ex-prosecutor Nazir Afzal who brought down Rochdale grooming gangs has instructed his lawyers to see if there is evidence to prosecute Boris Johnson for misconduct in public office as covid-19 death toll passes 100,000. Daily Mail 2021 Jan 26. https://www.daily-

mail.co.uk/news/article-9190235/Ex-CPS-chief-Nazir-Afzal-instructs-lawyers-consider-BorisJohnson-prosecution.html

20 McKee M, Gill M, Wollaston S. Public inquiry into UK's response to covid-19. BMJ 2020;369:m2052. doi: 10.1136/bmj.m2052 pmid: 32444349

21 Acharya A, Gerring J, Reeves A. Is health politically irrelevant? Experimental evidence during a global pandemic. BMJ Glob Health 2020;5:e004222.

doi: 10.1136/bmigh-2020-004222 pmid: 33097548

22 Ashton J. A fatal reckoning: UK reaches 100000 deaths from covid-19. Byline Times 2021 Jan 26. https://bylinetimes.com/2021/01/26/a-fatal-reckoning-uk-reaches-100000-deaths-fromcovid-19/

This article is made freely available for use in accordance with BMJ's website terms and conditions for the duration of the covid-19 pandemic or until otherwise determined by BMJ. You may use, download and print the article for any lawful, non-commercial purpose (including text and data mining) provided that all copyright notices and trade marks are retained. 